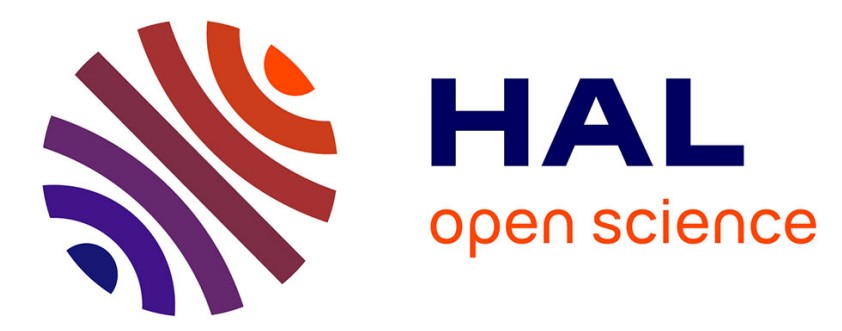

\title{
Socio-Emotional Support in French Hospitals: Effects on French Nurses' and Nurse Aides' Affective Commitment
}

Caroline Ruiller, Beatrice I.J.M. van Der Heijden

\section{To cite this version:}

Caroline Ruiller, Beatrice I.J.M. van Der Heijden. Socio-Emotional Support in French Hospitals: Effects on French Nurses' and Nurse Aides' Affective Commitment. Applied Nursing Research, 2016, 29, pp.229-236. 10.1016/j.apnr.2015.06.006 . halshs-01183182

\section{HAL Id: halshs-01183182 \\ https://shs.hal.science/halshs-01183182}

Submitted on 6 Aug 2015

HAL is a multi-disciplinary open access archive for the deposit and dissemination of scientific research documents, whether they are published or not. The documents may come from teaching and research institutions in France or abroad, or from public or private research centers.
L'archive ouverte pluridisciplinaire HAL, est destinée au dépôt et à la diffusion de documents scientifiques de niveau recherche, publiés ou non, émanant des établissements d'enseignement et de recherche français ou étrangers, des laboratoires publics ou privés. 
SOCIO-EMOTIONAL SUPPORT IN FRENCH HOSPITALS:

EFFECTS ON FRENCH NURSES' AND NURSE AIDES'

\title{
AFFECTIVE COMMITMENT
}

\author{
CAROLINE RUILLER \\ University of Rennes 1, Graduate School of Management \\ 11, rue Jean Macé \\ CS 70803, 35708 Rennes Cedex 7 \\ France \\ Tel : (33) 223237909 \\ $e$-mail : caroline.ruiller@ univ-rennes1.fr
}

\author{
BEATRICE I.J.M. VAN DER HEIJDEN \\ Radboud University Nijmegen, Institute for Management Research \\ P.O. Box 9108 \\ 6500 HK Nijmegen \\ the Netherlands \\ Open Universiteit in the Netherlands \\ University of Twente \\ The Netherlands \\ $e$-mail : b.vanderheijden@fm.ru.nl
}




\title{
SOCIO-EMOTIONAL SUPPORT IN FRENCH HOSPITALS:
}

\author{
EFFECTS ON FRENCH NURSES' AND NURSE AIDES'
}

\author{
AFFECTIVE COMMITMENT
}

\begin{abstract}
In spite of the differences in Human Resource Management (HRM) practices between the non-profit health care sector and business life, the majority of health care sector research appears to be based on the HRM (for Human Resources Management) blueprint for business life staff policy and practice. This study is aimed to better understand the impact of workplace social support in the context of French hospitals. Concrete, the first objective of this article comprises a thorough conceptualization and operationalization of workplace social support (i.e. both professional and personal social support). Data were collected in a French hospital among a sample of 62 respondents (for the qualitative part of our study), and among a sample of 171 health care professionals (nurses and nurse aids) (for the quantitative part of our study). Our outcomes indicate that, especially, personal support given by one's supervisor is strongly and positively related to nurses' and nurse aides' affective commitment. After a discussion about the outcomes, followed by some recommendations for future research, the article concludes with some practical implications for management in hospitals.
\end{abstract}

Key words: Workplace Social Support (Supervisor and colleagues; professional and personal), Affective Commitment, Nurses and Nurse aides, Hospitals. 


\section{INTRODUCTION}

While the problems of reconciling work and personal life - and the herewith related importance of organizational support - are increasingly recognized in France (OllierMalaterre, 2007), it is worth noting that specific legislation aimed at enabling employees to balance their work and family life is still lacking. At best, management of working organizations have incorporated this theme into their HRM policy and communicate it in their yearly economic, social and sustainable development reports. However, a sound translation into specific measures is absent in the majority of French working organizations.

Responsiveness of management in public sector institutions to employees' work-life balance struggles appears to be important for, at least, three reasons. Firstly, public sector institutions should focus on retaining employees in the nowadays' so-called 'moral crisis' (Couanau, 2003) context, in order to prevent absenteeism, turnover, or even withdrawal from the nursing profession as a whole (Authors, 2009). Secondly, respect for work-life balance is crucial for economic, social and environmental questions of effectiveness, given its impact on organizational performance (Mowday, Porter \& Steers, 1979). Thirdly, Sutton (2007), already indicated that employees and their managers have quite different conceptualizations of what comprises good management to realize their potential and to develop their talent for the benefit and the performance of the organization (Grant, 2012). The latter implies that more insight is needed into the role of workplace socio-emotional support in retaining nurses and nurse aids, and how to optimize professional and personal support in health care settings.

In France, the quality of interpersonal contacts at the workplace is assumed to be highly important, and employees have high expectations in this regard (Davoine \& Méda, 2009). Therefore, it is highly important to better understand how to conceptualize and to measure workplace social support within a French context. Academically, details on the reasoning behind specific conceptualizations of workplace social support are often lacking, 
and the validity and reliability of existing measures is sometimes weak, sometimes unknown, and sometimes even absent and/or incorporating very specific contextual aspects (Heitzman \& Kaplan, 1988).

The first objective of this contribution is to better understand the concept of workplace social support, and to come up with a psychometrically sound measurement instrument. We aim for a health care specific conceptualization, focusing upon the hospital sector in France. The second objective comprises the examination of the relationship between workplace social support and nurses' and nurse aids' affective commitment. Both qualitative and quantitative data have been used in order to test our research model.

Although all three components of organizational commitment (affective, continuance, and normative) (Allen \& Meyer, 1990) increase the likelihood that an employee will choose to remain within the organization, the nature of these psychological ties differs from one another. Affective commitment is characterized by a sense of belonging, pride and loyalty from the employee towards his or her organization (Ibidem, 1990), and allows him or her to feel psychological comfort, and to improve his or her sense of competence. Since the late 1980 's, the concept of affective commitment has been the core subject of attention in many scholarly publications, given its assumed correlation with the employee's performance. As affective commitment refers to the degree to which the employee identifies with, is involved in, and is emotionally attached to the organisation, we have decided to focus on this outcome variable in this contribution. After all, nurses' and nurse aides' dominant work orientation is based upon the fundamental concern for patients' welfare. Therefore, we believe that affective commitment, reflecting a belief in the goals and values of the hospital and the enjoyment of being a member of it, is the key issue here.

Even although affective commitment by itself is known to be strongly related to performance (Vandenberghe, Bentein \& Stinglhamber, 2004), social exchanges and norms of 
reciprocity should also be investigated to understand which types of workplace social support influence the identification between an individual and an organization (Hupcey, 1998). We therefore will study the predictive validity of workplace social support, which is assumed to be an important antecedent for nurses' and nurse aids' affective commitment to one's health care organization (see also Allen \& Shanock, 2013; Beehr, King \& King, 1990). Up to now, to the best of our knowledge, no previous scholarly research proposed a conceptualization of workplace social support that is specified for the French work context. There is a strong North-American bias in management research. Studies conducted in Europe often directly applied research models and measures developed in the US. Moreover, the measures were often translated and used abroad without their validity being carefully checked. However, the applicability of concepts and their measures in a non-US context should not be taken for granted (Boyacigiller \& Adler, 1991). After all, management activities, including HRM activities, are embedded in a national culture (Derr \& Laurent, 1989).

Since the beginning of the 1990's, in France, many reforms and reorganizations of health care institutions have resulted into significant differences as regards their internal organization (Belorgey, 2010). Hospital Patients' Territory Health's Law - whose components revolve around: (1) the regional health organization; (2) hospitals' governance; (3) access to care; (4) prevention; and (5) professional associations - has fundamentally changed the scope of actors' ${ }^{1}$ responsibility, whatever their hierarchical position. The so-called 'hospitalenterprise' is particularly criticized with respect to the weakening of the power of medical practitioners and caregivers to the benefit of the Hospital Director who him- or herself is actually feeling quite 'helpless' too (Pierru, 1999). In order to prevent drop-out of nurses, it is of huge importance to examine whether nowadays' management in hospitals is still able to provide their staff members with adequate support, especially in the light of new rules

\footnotetext{
${ }^{1}$ Hospital Director, Human Resources Director, Doctors, Nurses, Nurse aids
} 
regarding the evaluation of performances, and the great importance that is given to management control, its tools, and the management of projects (Mainhagu, 2012). The HRM practices associated to these new rules comprise an individualized logic that might be very different from, or even opposing, the previous HRM practices that were aligned with the identity of the health care professional's work, which was based on teamwork and cooperation (Bach \& Della Rocca, 2000).

Current practices essentially concern individualized evaluation, individualized compensation and individualized time scheduling with new responsibilities and roles delegated from HRM departments to local managers (Mainhagu, ibid) The core question in regard of these new rules is: Does management in French hospitals manage to support those whose primary activity is based on the caring itself?

\section{The CONCEPTUALIZATION OF WORKPLACE Social SUPPORT AND ITS IMPORTANCE IN THE Light OF AfFective CoMmitment}

The concept of workplace social support is rooted in the social exchange theory (Cropanzano \& Mitchell, 2005). Workplace social support is often associated to Perceived Organizational Support (POS) (Eisenberger, Huntington, Hutchinson \& Sowa, 1986) or Leader-Member eXchange (LMX) (Dienesh \& Liden, 1986). While Thomas and Ganster (1995) emitted a distinction between POS and supervisory support, with the latter referring to the efforts supervisors spent to compromise and/or to facilitate psychological and physical ergonomics for their employees, there is little information on the nature of 'supervisor-team members' exchange. As such, there is a need to better understand this specific from of workplace social support that is conceptually closer to LMX than to POS. LMX "may: (a) develop in a number of different ways; (b) differ in character based on which dimension(s) (i.e. affect, loyalty and contribution) is (are) prominent; and (c) lead to different outcomes depending upon the 
nature of the developmental process and the resulting characteristics of the relationship" (Dienesh \& Liden, 1986, p. 631). In this dyadic perspective (supervisor-employee), in order to be balanced, each party should offer something that the other party considers to be of value, and each party should perceive the exchange as fair and just.

Previously, scholarly literature on health psychology and social psychology differentiated between several types of workplace social support, including those of House (1981) and Karasek and Theorell (1990). According to House (table 1), workplace social support consists of four categories: (1) emotional support (expression of positive affects: confidence, empathy, love, benevolence); (2) evaluative (feedback, for example: "you did a good job"); (3) informative support (council to solve problems); and (4) instrumental support (effective assistance). According to Karasek and Theorell (1990, table 1), who distinguished between supervisory and collegial support, support from one's supervisor could exist of: (1) instrumental or technical support (loan or gift of money, material assistance); (2) receptivity support (availability of listening and paying attention to employees); (3) initiative support (degree of autonomy left to the employees); and (4) authority support (respect for the rules). Collegial support is conceptualised by the number of colleagues, and by its nature: (1) instrumental and (2) socio-emotional (number of colleagues considered as friends) support. 


\begin{tabular}{|c|c|c|c|}
\hline & & Type & Description \\
\hline \multirow{4}{*}{$\begin{array}{l}\text { House's Typology } \\
1985\end{array}$} & \multirow{4}{*}{ Workplace support } & Emotional & Friendship, love, comfort, sympathy \\
\hline & & Esteem & Reinsurance on skills and values \\
\hline & & Informational & $\begin{array}{l}\text { Advice, suggestions, contribution to knowledge on problems, } \\
\text { propositions to solve a problem }\end{array}$ \\
\hline & & Instrumental & $\begin{array}{l}\text { Effective assistance as a money loan / grant for material } \\
\text { goods, working time assistance }\end{array}$ \\
\hline \multirow{7}{*}{$\begin{array}{c}\text { Karasek \& } \\
\text { Theorell's Typology }\end{array}$} & \multirow{4}{*}{ Supervis or's support } & Instrumental & $\begin{array}{l}\text { Decision latitude in organizing tasks, suggestions for } \\
\text { improvement of working conditions, facilitating information, } \\
\text { exchange between team members, actions that promote } \\
\text { cohesion between team members }\end{array}$ \\
\hline & & Receptivity & $\begin{array}{l}\text { Attention paid to collaborators, availability to listen to } \\
\text { professional problems }\end{array}$ \\
\hline & & Initiative & Autonomy degree allowed to employees, self-organization \\
\hline & & Autority & Compliance, efforts \\
\hline & \multirow{3}{*}{ Colleagues' support } & Network & Number of colleagues \\
\hline & & Instrumental & $\begin{array}{l}\text { Efforts to do the job best, degree of autonomy in carrying out } \\
\text { missions, assistance to better solve professionals problems }\end{array}$ \\
\hline & & Socio-emotional & $\begin{array}{l}\text { Number of work colleagues considered as friends, } \\
\text { colleagues with similar interests }\end{array}$ \\
\hline
\end{tabular}

Table 1: Conceptualizations of Workplace social support.

Earlier empirical research has indicated the importance of workplace social support in the light of employee's performance and well-being (Beehr, Jex, Stacey \& Murray, 2000). Characterized by behaviours that lead an employee to believe that "she is appreciated and loved, estimated and being part of a network" (Cobb, 1976), workplace social support is found to be positively correlated to organizational commitment (Allen \& Meyer, 1990), and to negatively influence turnover and absenteeism (Shore \& Wayne, 1993). Employees with a supportive supervisor and near colleagues appear to be more satisfied with their work (Irvine \& Evans, 1995), and are more inclined to stay in their job (Karsh, Booske \& Saintfort, 2005).

Nurses' difficult working conditions (changing shifts, weekend work, high physical workload) along with the need for many nurses to combine work and family demands, 
logically evoke some rivalry, as they induce nurses to stress their own interests. Obviously, in the nursing profession, characterized by an emotionally demanding work setting, the quality of teamwork and support from close colleagues are extremely important throughout the career. By taking both workplace social support from one's direct supervisor, and from one's near colleagues into account, our research is in line with the so-called relational perspective (Mossholder, Setton \& Henagan, 2005).

Unfortunately, HRM has long been based on the so-called 'separation model' (Kirshmeyer, 1995), that implies that employers are only focused upon employees' work life performance and are aimed to make sure that they fulfil their task obligations, while ignoring their 'non-professional' or private life. This implies that the employee him- or herself was interpreted to be the sole responsible person for coping with difficulties associated with family responsibilities (ibidem, 1995). We therefore argue that following the previously explained relational perspective (Mossholder et al., 2005) is urgently needed in order to respond to nowadays' need for employees to combine the ever-increasing work and private life demands (De Vos \& Author, 2015).

Moreover, as a result of the definition's plethora and its multidisciplinary character (Winemiller, Mitchell, Sutliff \& Cline, 1993), a researcher within the domain of workplace social support is confronted with the need to study the concept, taking into account three questions, in order to capture its broader cultural context (see also Cohen \& Syme, 1985): Is workplace social support expected by the employee? Is it accepted by him or her? And is it actually received? Moreover, previous scholars in the field have stressed that the evaluation of workplace social support is associated with a contingency, that is to say, a (dis)congruency between the provider's and the recipient's support perceptions [see Hupcey (1998), when considering the complexity of definitions (intentions of supportive behaviours, recipient's perception, types of support, and perceived reciprocity). Based on our literature review, we 
stress the importance of identifying the nature of the social support that is exchanged, by both supervisors and near colleagues, in order to determine the (dis)congruence of perceptions between those who "give" and those who are "waiting to receive", and to test their predictive validity in the light of employees' affective commitment.

Based upon the literature review given above, the following hypotheses have been formulated:

Hypothesis 1 . Workplace social support is positively related to affective commitment.

H1.a Supervisory support is positively related to affective commitment.

H1.b Collegial support is positively related to affective commitment.

\section{METHODOLOGY OF THE QUALITATIVE APPROACH}

62 semi-structured interviews have been conducted in a regional hospital in Brittany (a region in the West of France) including the Director $(\mathrm{N}=1)$, the Human Resource Director $(\mathrm{N}=1)$, a sample of local supervisors $(\mathrm{N}=30)$, and a sample comprising nurses and nurse aids $(\mathrm{N}=30)$ (dyadic approach: supervisors and employees). The interviews were focusing around two themes: (1) the quality of the supervisor-team members' relationship, and (2) the nurses' and nurse aids' work content. Apparently, expectations in terms of workplace support may vary depending on both the qualitative and quantitative workload specific nurses and nurse aids experience. Therefore, concrete information about the work content was needed in order to be able to analyse and interpret the results in a meaningful way.

The Director's openness allowed us a total immersion into our research topic from the very beginning. Being in a role as participant observer, the first author witnessed situations of 'formal discussion' (transmission) and situations of 'informal discussion' (coffee breaks, 'festive' meetings in the team supervisors' absence, et ceteras). Next to these rich observations, an ample amount of semi-structured interviews were held. The interview with 
the Director concentrated on his opinion about the external environment (the competitive clusters of the establishment, mentoring, certification) and about the internal context (social climate, work load and psychological work demands). The interview with the Human Resource Director dealt with nurses' and nurse aids' absenteeism and the solutions he was expecting, to reduce absenteeism. As indicated above, thirty interviews were conducted with the local managers, and thirty interviews were held with thirty of their team members (nurses and nurse aids). By constraining the social support to the network of the nurse in his or her health care institution, we have not attempted to measure one's social support network in accordance with Barrera's definition (1986), referring to the total number of social relationships a person has established with others, the frequency of social contacts, and the intensity of links.

Our previously explained theoretical framework was used to design the interview protocol, however, the emergence of new dimensions during conducting the interviews was allowed and has enriched our data and its analysis. In addition, a diary was kept in order to gather information on the meeting places (office, clinic room, office managers, et ceteras) as well as on descriptive elements of these places (usability, furniture placement, et ceteras). We also reported themes that were covered during the interviews, such as, the open conflicts of which we have been spectators, 'impressions' that emerged during the interviews, and information on the situational elements (location of break rooms in the service, doctor's position concerning the research process, doctors/local managers/nurse and nurse aids relationships etceteras).

Despite the construction of a semi-structured interview guide in the first phase of the study, we finally opted for continuing with unstructured interview protocols given the unexpected responses expressed by the interviewees in relation to the themes. From this nondirectional position That is to say, while conducting the interviews, we have gradually 
evolved from a semi-structured approach via quasi-directive interviews to a non-directional approach, supported by a content analysis in real time (Glaser \& Strauss, 1967).

\section{QUALITATIVE RESULTS: SOCIO-EMOTIONAL WORKPLACE SUPPORT AND ITS}

\section{ASSOCIATION WITH AFFECTIVE COMMITMENT}

The interview outcomes led us to identify five different categories of representations indicating the diversity of perspectives and perceptions on workplace social support: (1) the recognition of a need for help, (2) the desire to give, (3) the possibility of giving, (4) the expectations of 'recipients' and (5) what is 'really' felt by 'recipients'. Our qualitative results also stressed the prevalence of difficulty in recognizing those situations where support expression is needed. For example, a manager's positive portrayal of his or her actions providing support to certain employees (taking into consideration the family situation to foster development of schedules, for example) does not necessarily mean that it is perceived positively by his or her employees as well. More specifically, the link between a manager's positive portrayal and the perception of support received by the nurses and nurse aids may be mediated by contextual, situational or individual constraints lived and/or perceived by both parties in the exchange relationship.

\section{Paradoxes and ambiguity of workplace social support: The diversity of perspectives}

The recognition of a need for help is often expected in problematic situations. From the interviews, we may conclude that opening hours, work demands, workload, interpersonal conflicts and personal issues with 'work and private life spill-overs' were the most significant. All participating managers recognized the daily importance of adopting an empathic attitude towards their team members in order to create a good working climate, and to increase the amount of high-quality leader-member exchanges. However, the recognition of a need for 
social support is not necessarily associated with the desire to give. A relevant example of our qualitative study concerns the finding that some managers and members considered personal issues to be too intimate to be expressed at work. As a consequence, they kept their own professional and personal issues separated, leading them to be only professionally supporting their members/colleagues and to exclude personal attention at work.

The possibility or more appropriate in this regard, the impossibility of giving essentially refers to the lack of time for social exchanges. Organizational, work and relational hindrances, such as a too high amount of work demands, workload intensification with the "T2A tariff list", , blurred job descriptions leading to individualization and disappearance of team working collectives, the new management systems with the computer aid associated to the traceability, the size of the team (for example, too much members to manage), a lack of recognition of the real workload compared to the amount of stipulated work of caregivers, staffing shortage and the lack of replacing staff were mentioned as concrete examples aimed to specify the lack of time for social exchanges. At an individual level, the personality of one's manager or one's near colleague, the managerial style and the personal characteristics (gender, age et ceteras) were added as possible factors that might influence the possibility to express support with one another. Regarding these various hindrances, social exchanges are estimated to decrease, in the first place, in case the workload is intensified, which even worse just leads to a further increase in the actual need for social support over time.

The content analysis led us to identify that under these circumstances, workplace social support is essentially expected to be socio-emotional. Unfortunately, except for two nurses, a gap was identified between the expectations and the tangible behaviours of social support by all the nurses and nurse aids who were interviewed. More specifically, the

\footnotetext{
${ }^{2}$ The French DRG, system is based on the Tarification à l'Activité (T2A) tariff list, which sets the actual reimbursement rates behind each case payment. This tariff list was associated with Hospital Patients' Territory Health's Law.
} 
subjective evaluation of the social support given by their managers was more negative compared to the collegial support felt. That is to say, it is easier to feel supported by coworkers in one's team, or otherwise stated, a nurse or nurse aid might have a better chance of finding a colleague whose personal values fit with his or her own values, and to feel actually supported by him or her.

\section{What is social support in a hospital? Why is it associated with affective commitment?}

Our contribution is aimed at a better understanding of paradoxes with regard to personal support as well:

"It's very surprising to speak of social support at work ... Here, it is a difficult subject to discuss because we are asked not to speak and not to express our emotions at work"

From our empirical work, we have found that many interviewees experienced more or less difficulty to clarify/define what 'personal' encompasses. Some nurses and nurse aids appeared to associate 'personal' to an intimate sphere, while others associated it with 'nonwork' issues. As an example, when managers experienced problems with regard to the harmonization of schedules, nurses and nurse aids complained of the instability of their work load, and the impossibility for them to plan their lives 'off work'. In addition, they reported that they did not express to their manager that, in fact, they really suffered from a lack of emotional support. On the other hand, nurses and nurse aids recognized that the lack of openness of their supervisor and themselves to elaborately discuss their emotions may also constitute a barrier to efficiency in nursing care. That is to say, the expression of emotions, in case it is done in a situation of mutual trust, is assumed to enhance the quality of the relationship between the 'manager' and his or her subordinates, and between subordinates among one another. According to the respondents, a sound expression of social support in the workplace requires active listening, responsiveness, openness to others, recognition and understanding of 'social perceptions' from one another. 
These paradoxes regarding "personal support" appeared to be important for three reasons. Firstly, how can the influence of "personal support" be evaluated if there is no possibility to express this type of behaviours? Secondly, how can an individual employee identify her or himself to important stakeholders in the organization if the organization does not allow emotional expression? And, how can an employee be affectively committed (by a sense of belonging, pride and loyalty) to her or his organization (Allen \& Meyer, 1990) if the organization/the employer does not care about her or his well-being (Eisenberger, Huntington, Hutchinson \& Sowa, 1986), and more precisely, one's emotional well-being, in case, the HRM policy and practices in the organization are based on the "separation model" (Kirshmeyer, 1995)?

Our in-depth qualitative approach enabled us to find out that "personal support" was needed, yet, paradoxically, not provided, by the health care organization. While professional support attributes were rather easy to determine (esteem, recognition, et ceteras), it should be noted that the integration of personal problems and the individual intimate sphere were a sensitive issue - sparking tensions - to deal with. The failure to take into account the nurses and nurse aids' emotions by the Hospital's management (recognized by 19 local managers (out of the 30 participating), and by 24 nurses and nurse aids (out of 30) constitutes a brake on the expression of socio-emotional and/or formalization of an expectation by a nurse or nurse aid who is 'in need'. However, our qualitative approach did not allow us to elucidate on, and to determine, the influence of personal support on affective commitment, herewith stressing the importance to continue with our scholarly work in a quantitative way. 


\section{METHODOLOGY OF THE QUANTITATIVE APPROACH}

\section{Procedure and sample}

Data have been gathered using a sample of 350 nurses and nurse aids working in the French hospital. 171 usable questionnaires were returned ${ }^{3}$, representing a response rate of $48.8 \%$. The final sample comprised $95 \%$ of female staff. $57 \%$ of the respondents had less that 5 years of seniority in the hospital, and $60 \%$ had less than 5 years of seniority in the health care profession as a whole. To measure the model variables, scales have been selected, on the one hand, for their psychometric properties, and, on the other hand, in case they were assumed to be suitable for use in a French context. The translation-back-translation method has been used for each country (Hambleton, 1994), i.e. the measurement instrument has been translated from one language to another and then back-translated to the original language by an independent translator. The purpose of this double translation was to allow experts to examine both versions of each questionnaire item to establish conformity of meaning. Where inconsistencies were, the items have been reformulated or, if applicable eliminated.

Workplace social support was measured by means of a newly developed scale (see Appendix A for the full item list), with an example item being: "My manager/my team has empathy toward me" (Author, 2011 ; Authors, 2014) (Cronbach's alpha was .84 for the professional support from supervisor, .74 for the personal support from supervisor, .90 for the collegial support scale).

Organizational commitment was assessed by the affective commitment subscale developed by Meyer, Allen and Smith (1993), which was already validated in a French context (Dumas, 1999). Six items were used, referring to emotional involvement, for example: "I really feel the problems of the organization as if they were mine" (Cronbach's alpha was .71).

\footnotetext{
${ }^{3}$ The questionnaires were administrated in the health services, accompanied by a return envelope.
} 


\section{Exploratory and confirmatory factory analysis}

For each measurement instrument in this study, we investigated its internal consistencies (using KMO for Keizer-Meyer-Olhin, and Bartlett's test for sphericity that is closer to khi 2 adjustment) and its factor structure (SPSS 15.0). Subsequently, for each measurement scale, the number of axes was determined using the Kaiser's method (Eigenvalue greater than 1), and multi-dimensional constructs' rotations were performed in order to obtain a clear-cut factor structure. Internal consistency was also assessed by Cronbach's alpha.

A second step consisted of establishing the validity of the measures (using AMOS 7.0). The research model's absolute scaling was assessed by means of the $\mathrm{Chi}^{2}$ index, the GFI and the RMSEA, while the incremental adjustment was tested using the NFI, the TLI and the CFI indices. As recommended by Fornell and Larcker (1981), we verified whether each latent variable shared, at least, $50 \%$ of the variance with its corresponding manifest variables, by relying on rho's convergent validity index, while the discriminant validity of the measurement scales was determined by investigating the correlation between the different scales.

\section{OUTCOMES OF THE QUANTITATIVE APPROACH}

The exploratory and confirmatory factor analysis showed reliable and valid results (see a summary of the outcomes in Table 2 and see Appendix B for all items proposed). It is worth stressing two types of specific results. Firstly, for all measurement tools, based upon the factor-analytic outcomes, several items have been removed. The most significant example concerns the affective commitment measure which was reduced to two items: "I don't feel like a family member", and "I don't feel a strong sense of belonging within the hospital". Secondly, elaborate tests aimed at determining the factor-analytic structure of the workplace social support measures (supervisory and collegial support) revealed two different factor 
structures. The supervisory support scale appeared to be composed of two factors (one factor for 'professional' and one factor for 'personal or person-oriented support'), while the colleague support scale appeared to be one-dimensional (however, both including professional and personal items). The supervisory support scale, being bi-dimensional, led us to refine Hypothesis 1.a:

H1.a.1. Professional supervisory support is positively related to affective commitment.

H1.a.2 Personal supervisory support is positively related to affective commitment.

Moreover, the discriminant validity for distinguishing between the two supervisory support dimensions was not supported given the outcomes for two model test indicators: (1) the RMSEA (being > 0.08), and (2) the high correlation between the two dimensions $(r=0.6)$. However, given the theoretical references on which the research protocol was based (HRM 'separation' model; Kirshmeyer, 1995), and given the results of the exploratory qualitative interview outcomes (stressing the distinction between professional and personal support), we concluded that maintaining the two factors appeared to be important for further analyses. 
TABLE 2

Exploratory and Confirmatory Factor Analysis

\begin{tabular}{|c|c|c|c|c|c|c|c|c|c|c|c|}
\hline \multicolumn{2}{|c|}{ DEPENDENT VARIABLES } & $\begin{array}{l}\text { Cronbach's } \\
\text { Alpha }\end{array}$ & $\begin{array}{c}\text { number of } \\
\text { items } \\
\text { selected }\end{array}$ & GFI & RMSEA & NFI & TLI & CFI & Reliability (Rhô) & $\begin{array}{l}\text { Validity } \\
\text { (Rhô) }\end{array}$ & Discriminant Validity \\
\hline \multicolumn{2}{|c|}{ Affective commitment } & 0,71 & 2 & & & & & & & & \\
\hline \multicolumn{2}{|c|}{ INDEPENDENT VARIABLES } & $\begin{array}{c}\text { Cronbach's } \\
\text { Alpha }\end{array}$ & $\begin{array}{c}\text { number of } \\
\text { items } \\
\text { selected }\end{array}$ & GFI & RMSEA & NFI & TLI & CFI & Reliability (Rhô) & $\begin{array}{l}\text { Validity } \\
\text { (Rhô) }\end{array}$ & Discriminant Validity \\
\hline \multirow{2}{*}{$\begin{array}{l}\text { Social support from } \\
\text { supervisor } \\
\end{array}$} & Professional & 0,90 & 6 & \multirow{2}{*}{0.91} & \multirow{2}{*}{0.12} & \multirow{2}{*}{0.92} & \multirow{2}{*}{0.91} & \multirow{2}{*}{0.94} & 0.98 & 0.92 & \multirow{2}{*}{ (Pro -Perso) 0.6} \\
\hline & Personal & 0,79 & 3 & & & & & & 0.81 & 0.80 & \\
\hline \multicolumn{2}{|c|}{ Social support from Co-Workers } & 0,91 & 8 & 0.95 & 0.07 & 0.91 & 0.94 & 0.96 & 0.98 & 0.92 & \\
\hline
\end{tabular}


PLS (partial least square regression) is suitable for analyzing a relationship between two variables that are highly correlated, herewith controlling for multi-collinearity. In our specific case, PLS regression analysis allows, on the one hand, to compare the predictive validity of the three support types among one another, and, on the other hand, to compare the differences in impact between workplace social support and affective commitment. In fact, we chose PLS because of the risks associated with the high correlation between the professional and the personal support of supervisor. In regression analysis, the selection of relevant factors can be problematic when the exogenous variables are highly correlated with each other. More specifically, in the case of the method of least squares, the multi-collinearity between the exogenous variables $(\mathrm{X})$ generally results into high variance estimators that can lead to reject their significance while these variables are highly correlated with the endogenous variable Y. It is precisely for this limitation that the technique of PLS has been developed. This technique allows to analyze and understand complex relationships between exogenous (Y) and endogenous (X) variables that can be highly correlated. PLS regression is a combination of the NIPALS algorithm developed by Wold (1966), for the principal component analysis, and the PLS approach, proposed by Wold (1975), to estimate structural equation models of latent variables. PLS regression allows us to test the impact of high perceptions versus low perception levels for the endogenous variables. All the endogenous variables are coded into binary dummy variables ${ }^{4}$. Several validation steps were executed in order to test model assumptions preceding the model tests Table 2 shows the PLS regression outcomes, and the sensitivity coefficients associated with each explanatory variable. These coefficients are given by the equation of regression: the contribution of each variable is estimated by the statistical variable importance in the projection.

\footnotetext{
${ }^{4}$ « Dummy Variables »: Each variable is coded 0 or 1 to distinguish between two groups.
} 


\section{Workplace Social Support and Affective Commitment among hospital nurses and nurse} aids

TABLE 1

Sensitivity Coefficients ${ }^{5}$

\begin{tabular}{|c|c|}
\hline Variables & $\begin{array}{c}\text { Affective } \\
\text { Commitment }\end{array}$ \\
\hline Constant & 2,577 \\
\hline $\begin{array}{c}\text { Professional Supervory } \\
\text { Support }\end{array}$ & 0,08 \\
\hline $\begin{array}{c}\text { Personal Supervisory } \\
\text { Support }\end{array}$ & 0,116 \\
\hline Collegial Support & 0,068 \\
\hline
\end{tabular}

The PLS regression equation outcomes highlight the significant and positive effect of supervisory personal support on nurses' and nurse aids' affective commitment, herewith supporting H1.a.2. Moreover, our outcomes indicate positive effects of professional supervisory support and collegial support in the light of nurses' and nurse aids' affective commitment, herewith also supporting H1.a.1 and H1.b.

\section{DISCUSSION}

\section{Reflection upon the outcomes}

In the light of current concerns about nurse shortages in Western countries (Aiken, Clarke, Sloane, Sochalski \& Silber, 2002; Chan, Tam, Lung, Wong \& Chau, 2013), nurses’ commitment and retention are a topic of great importance. Compared to other professional groups, nurses tend to have high levels of workload and burnout (Aiken \& al., ibid). At the same time, demographic changes have led to an aging nursing workforce, a decline in the

\footnotetext{
${ }^{5}$ The sensitivity coefficients are part of a more complex model integrating work strains. The results exposed here, only concern workplace social support.
} 
graduates entering the profession, and an increase in the need for care as the "baby boomers" generation approaches retirement (North, Erasmussen, Hughes, Finlayson, Ashton, Campbell \& Tomkins, 2005).

Therefore, the objective of the present research was to examine the value of social support as an HRM practice to help responding to the issues given above. This article started by underlining the absence of a consensus on the definition of workplace social support. While supervisory and co-workers' support are recognized to be important for employees' well-being and affective commitment (Coyle-Shapiro \& Kessler, Kossek \& Oseki, 1998; Thomas \& Ganster, 1995), the character of these types of support still have to be clarified by researchers in Management Science considering the complexity of the definitions (Hupcey, 1998). In addition, and as an operational consequence, the reliability and the validity of social support scales are sometimes weak, sometimes unknown, and sometimes even absent (Beauregard \& Dumont, 1996). Having used qualitative data, on the one hand, in order to analyse the nature of workplace support and its paradoxes, and quantitative data, on the other hand, in order to study the effect of workplace social support on affective commitment, we may conclude that interpersonal exchanges in the daily work situation are crucial.

More specifically, the outcomes of our current research indicates that personal supervisory social support (empathy, listening and communication on personal problems) seems to be more important in comparison with professional supervisory support (esteem, respect, trust, reinsurance on professional skills and arrangement with the scheduling) or collegial support (encouragement, help to relativism, esteem, protection, reinsurance on professional skills, communication on personal problems et ceteras). Considering only the qualitative results, personal supervisor support was not expected to have the most important influence on employees' affective commitment. 
Notwithstanding the reported importance of empathy and the listening to personal problems, supervisors often don't feel comfortable with these aspects of their relational skills, leading them to an emotional labour (Hochschild, 1979) on their own reactions toward their employees. As a consequence, core attention should be given to the optimal character of emotion-elucidation by supervisors in order to provide sound social support and to increase nurses' and nurse aids' affective commitment to health care institutions (see also Dunham, Pierce \& Castenada, 1987). However, the expression of workplace social support must be coupled with changes in the structure and culture of the organization, and regarding HRM policy practices as well; otherwise management will risk, to observe very limited effects (Lewis, 2001; Rapoport, Bailyn, Fletcher \& Pruitt, 2002).

Nurses and nurse aids' themselves also have an important role to play in the interpersonal environment by providing their colleagues with support, but also by asking for support when needed. Our qualitative findings indicate that social support requires interaction and, as such, the quality of the exchange of support largely depends not only on those who provide it but also on those who need it. As nurses' dominant work orientation is based upon the fundamental concern for patients' welfare, it is important to carefully monitor the character of their job in order to guide the degree of organizational and professional commitment (commitment to one's profession) (see also Meyer, Allen \& Smith, 1993).

It is important for health care institutions to carefully pay attention to finding ways of increasing the opportunities to obtain social support for all staff members and by all parties involved. Social support could be improved, for example, by creating social networks. As employees working in nursing are exposed to emotional involvement, stress, work constraints and role uncertainty, the need to talk things through with supervisors and with near colleagues is strongly apparent. When it comes to situations of psychological stress, colleagues and 
supervisors appear to be the most important source of support (Beehr et al., 2000), particularly when institutionally that kind of support is lacking (Kirpal, 2004).

Unfortunately, our study indicates that many nurses and nurse aids perceive the institutional support mechanisms as inadequate and not supportive in practice. Managers in health care settings that cannot provide satisfactory social support, and that fail to discover such deficiencies in good time will experience growing levels of dissatisfaction, and a decrease in affective commitment, that might even result in premature departure. If the nature of the deficiencies is only slight, job satisfaction and morale are reduced. If it is more serious, affective commitment will decrease, and turnover intentions will increase, impacting upon corporate growth and long-term performance (Chen, Chang \& Yeh, 2004). We advocate that, next to a sincere involvement of supervisors with the well-being and work-home interference of their staff in health care settings, there is a serious need for more social support networks aimed at increasing collegial support as well. Integrating this relational perspective, by focussing on empathy and consideration for individual needs in everyday practice, is assumed to result in better working lives, and herewith to increase the coping strategies nurses and nursing aids have to combine work and private life.

Only if nurses and nurse aids love their profession and perceive their organisation as a place where they can fulfil work-related desires and can combine work and private life in a sound way, will their affective commitment increase. As the amount of affective commitment (the degree to which the employee identifies with, is involved in, and is emotionally attached to the organisation) (see also Meyer, Allen \& Smith, 1993) develops mainly in one's earlier career stages, it is extremely important to start paying attention to work- and family-related abilities, needs and desires of individual nurses and nurse aids right from the time of their recruitment, in order to adjust social support networks to the specific individual needs. 


\section{Research limitations and future research}

Our research has several limitations that should be noted. First, we did not test an elaborate model, such as for example, the Job Demand-Resource (JD-R) model (Bakker, Demerouti, De Boer \& Schaufeli, 2003) to analyse the amount of variance in affective commitment that is explained by several job and individual characteristics. Second, our research model could be extended with moderating factors, such as age, seniority, gender et ceteras, as well. Third, longitudinal research is needed to obtain more insight into the pattern of causal relationships and long-term effects. Future research could investigate (the need for) social support, from an individual, an organizational, and a social perspective, in the light of affective commitment, performance, and turnover (intention). Both the quality and quantity of health care that is provided now, and that will be provided in the future, is at stake. By monitoring a broader arsenal of nurses' and nurse aids' precursors of affective commitment, and its consequences, health care organizations may be able to prevent premature loss of capabilities, knowledge and commitment, in order to secure the supply of health care for future.

\section{REFERENCES}

Aiken, L.H., Clarke, S.P., \& Sloane, D.M. 2000. The magnet nursing services recognition program: A comparison on two groups of magnet hospitals. American Journal of Nursing, 100: 26-36.

Aiken, L.H., Clarke, S.P., Sloane, D.M., Sochalski, J., \& Silber, J.H. 2002. Hospital nurse staffing and patient mortality, nurse burnout, and job dissatisfaction. Journal of the American Medical Association, 288 :1987-94. 
Allen, D. G., \& Shanock, L. R. (2013). Perceived organizational support and embeddedness as key mechanisms connecting socialization tactics to commitment and turnover among new employees. Journal of Organizational Behavior, 34(3), 350-369.

Allen, T.D., Herst, D.E.L., Bruck, C.S., \& Sutton, M. 2000. Consequences associated with work-to-family conflict: a review and agenda for future research. Journal of Occupational Health Psychology, 5: 278-308.

Allen, N.J., \& Meyer, J.P.1990. The measurement and antecedents of affective, continuance and normative commitment to the organization. Journal of Occupational Psychology, 63: 118.

Bach, S., Della Rocca, G. 2000. The management strategies of public service employers in Europe. Industrial Relation Journal, 31, 2 :82-96.

Bakker, A.B., Demerouti, E., Taris, T., Schaufeli, W.B., \& Schreurs, P. 2003. A multi-group analysis of the job demands-resources model in four home care organizations. International Journal of Stress Management, $10: 16-38$

Barrera, M. 1986. Distinctions between social support concepts, measures and models. American Journal of Community Psychology, 4 : 413-445.

Beehr, T.A, King, L.A., \& King, D.W. 1990. "Social support and occupational stress : talking to supervisors". Journal of Vocational Medicine. Vol. 36, 61-81

Beehr, T.A, Jex, S.M., Stacey, B.A., \& Murray, M.A. 2000. "Work stressors and co-worker support as predictors of individual strain and job performance”. Journal of Organizational Behavior, $21: 391-405$.

Belorgey, N. 2010. L'hôpital sous pression. Enquête sur le nouveau management public. Paris : La Découverte.

Beauregard L., Dumont S. 1996. La mesure du soutien social. Service social, vol. 45, p. 5576 
Boyacigiller, N., \& Adler, N. 1991. The parochial dinosaur: Organizational science in a global context. Academy of Management Review, 16 :262-290.

Chan, Z. C., Tam, W. S., Lung, M. K., Wong, W. Y., \& Chau, C. W. (2013). A systematic literature review of nurse shortage and the intention to leave. Journal of Nursing Management, 21(4), 605-613.

Chen, T.Y., Chang, P.L., Yeh, C.W. 2004. A study of career needs, career development programs, job satisfaction and intention to turnover intention of RandD personnel. Career Development International, 9 : 424-437.

Cobb, S., 1976. Social support as a moderator of life stress. Psychosomatic Medicine, 38: 300-314.

Cohen, S., \& Syme, S.L. 1985. Issues in the study and application of social support, In, Social Support and Health (pp. 3-22),, Cohen S., Syme S.L. Orlando, Florida, Academic Press.

Couanau, R. 2003. Rapport sur l'organisation interne de l'hôpital, Assemblée Nationale.

Coyle-Shapiro, J.A-M., \& Kessler, I. 2000. Consequences of the psychological contract for the employment relationship: A large scale survey. Journal of Management Studies, 37 : 903-930.

Cropanzano, R., Mitchell, M. 2005. Social Exchange Theory: An Interdisciplinary Review, Journal of Management, $31: 874-900$.

Cropanzano, R., Rupp, D.E., \& Byrne, Z.S. 2003. The relationship of emotional exhaustion to work attitudes, job performance and organizational citizenship behaviours. Journal of Applied Psychology, 88: 160-169.

Davoine, L., \& Méda, D. 2009. Quelle place le travail occupe t-il dans la vie des français par rapport aux Européens ? Informations Sociales, 153 : 48-55. 
Derr, C.B., \& Laurent, A. 1989. The internal and external career: a theoretical and crosscultural perspective. In: M.B. Arthur, D.T. Hall \& B.S. Lawrence (Eds.), Handbook of Career Theory. Cambridge: Cambridge University Press.

De Vos, A., \& Author, B. (Eds) (2015). Handbook of Research on Sustainable Careers, Cheltenham, UK and Northampton, MA, USA: Edward Elgar Publishing.

Dienesh, R.M., \& Liden, R.C. 1986. Leader-member exchange model of leadership: a critique and further development. Academy of Management Review, 11:618-634.

Dunham, R.B., Pierce, J.L., \& Castenada, M.B. 1987. Alternative work schedules: Two field quasi-experiments, Personnel Psychology, 40: 215-240.

Dumas, M., 1999. Temps partiel et analyse du changement de l'implication organisationnelle : une application quasi-expérimentale. Thèse de doctorat en Sciences de Gestion, Université de Paris I Panthéon-Sorbonne, Paris.

Einsenberger, R., Huntington, R., Hutchinson, S., \& Sowa, D., 1986. Perceived organizational support. Journal of Applied Psychology, 75:51-59.

Fornell, C., \& Larker, D.F. 1981. Evaluating structural equations models with unobservable variables and measurement error. Journal of Marketing Research, 18:39-50.

Glaser, B. G. \& Strauss, A. L. 1967. The Discovery of Grounded Theory: strategies for qualitative research. Chicago : Aldine.

Grant, A.M 2012. Leading with meaning: beneficiary contact, prosocial impact, and the performance effects of transformational leadership. Academy of Management Journal, 55(2) : 458-476.

Hambleton, R.K. 1994. Guidelines for adapting educational and psychological tests: A progress report. European Journal of Psychological Assessment (Bulletin of the International Test Commission). 10:229-244. 
Heitzmann, C.A., \& Kaplan, R.M. 1988. Assessment of Methods for Measuring Social Support. Health Psychology, 7: 75-109.

Hochschild, A.R. 1979. Emotion work, feeling rules and social structure, American Journal of Sociology, 85 :551-575.

House, J.S. 1981, Work, Stress and Social Support, Addison-Wesley, Reading, MA.

Hupcey, J.E. 1998. Clarifying the social support theory-research linkage, Journal of Advanced Nursing, $27: 1231-1241$.

Irvine, D.M, \& Evans, M.G. 1995. Job satisfaction and turnover among nurses : integrating research findings across studies. Nursing Research, 44 : 246-253.

Karsh, B., Booske, B.C., \& Sainfort, F. 2005. Job and organizational determinants of nursing home employee commitment, job satisfaction and intent to turnover. Ergonomics, 48 : 12601281.

Kirpal, S. 2004. Work identities of nurses. Between caring and efficiency demands. Career Development International, 9, 3 : 1257-1286.

Kirshmeyer, C, 1995. Managing the work-nonwork boundary an assessment of organizational responses. Human Relations, 48, 5 : 515-536.

Kossek E.E., Oseki C..1998. Work-family conflict, policies, and the job-life satisfaction relationship : A review and directions for organizational behavior-human ressources research. Journal of Applied Psychology, Vol. 83, No 2, p. 139-149.

Lewis, S. 2001. Restructuring workplace cultures: the ultimate work-family challenge? Women in Management Review, $16: 21-29$.

Mainhagu, S. 2012. Le pouvoir paradoxal des soignants sur la GRH. @GRH, 4 : 33-52.

Meyer, J.P., Allen, N.J., Smith, C. 1993. Commitment to organizations and occupations : extension and test of a three component conceptualization. Journal of Applied Psychology, Vol. 78, p. 538-551 
Mossholder, K.W., Settoon, R.P.,\& Henagan, S.C. 2005. A relational perspective on turnover : examining structural, attitudinal, and behavioral predictors, Academy of Management Journal, 48 : 607-618.

Mowday, R.T., Porter, L.W., \& Steers, R.M. 1979. The measurement of organizational commitment. Journal of Vocational Behaviour, 14, 224-247.

North, N., Rasmussen, E., Hughes, F., \& Finlayson, M.. 2005. Turnover amongst Nurses in New Zealand District Health Boards: A National Survey of Nursing Turnover and Turnover Costs. Journal of Employment Relations Auckland, 30:49-63.

Ollier-Malaterre, A. 2007. Gérer le hors-travail ? Pertinence et efficacité des pratiques d'harmonisation travail - hors-travail, aux Etats-Unis, au Royaume-Uni et en France, Thèse de Doctorat en Sciences de Gestion, ESSEC, Paris.

Pierru, F. 1999. «L'hôpital entreprise». Une self-fulfilling prophecy avortée. Politix, 12 :747.

Rapoport R., Bailyn L., Fletcher J., \& Pruitt B. 2002. Beyond Work-Family Balance: Advancing Gender Equity and Workplace Performance, London, Wiley.

Authors 2014. Socio-Emotional support at work: effects on French nurses' job strain and affective commitment, Academy of Management Annual Conference, Philadelphia.

Author 2011. Le talent des managers de proximité », L'ère des talents. Revue Internationale de Psychosociologie, XVII, $\mathrm{n}^{\circ} 41$, Editions ESKA.

Shore L., \& Wayne S. 1993. Commitment and employee behaviour: Comparison of affective and continuance commitment with perceived organizational support, Journal of Applied Psychology, 78:774-780.

Sutton R.I. 2007. The No Asshole Rule: Building a Civilized Workplace and Surviving One That Isn't, Business Plus Eds. 
Thomas T.T., Ganster D.C. 1995. «Impact of family-supportive work variables on work family conflict and strain: a control perspective », Journal of Applied Psychology, 80 : 6-10. Author, Van Dam K., Hasselhorn H.M. 2009. Intention to leave nursing. The importance of interpersonal work context, work-home interference, and job satisfaction beyond the effect of occupational commitment. Career Development International, 14(7) : 616-635

Author 2002. Prerequisites to guarantee life-long employability. Personnel Review, 31 : 4461

Vandenberghe C., Bentein K., \& Stinglhambert F. 2004. Affective commitment to the organization, the supervisor and workgroup : antecedents and outcomes. Journal of Vocational Behaviors, 64 : 47-71

Winemiller D.R.., Mitchell M.E., Sutliff J., \& Cline D.J. 1993. Measurement Strategies in Social Support: A Descriptive Review of the Literature. Journal of Clinical Psychology, 49: 638-648.

Wold H., 1966. Estimation of principal components and related models by iterative least squares, In P.R Krishnaiah., Multivariate Analysis, (pp. 391-420), New York, Academic Press.

Wold H. 1975. Soft modeling by latent variable: the non-linear iterative partial least squares (NIPALS) approach, Perspectives in Probability and Statistics, p. 117-142. 


\section{APPENDiX A : WorkPlace SOCIAL SUPPORT SCAlE (AUTHORS, 2008)}

1. My supervisor / co-workers listen to my professional problems.

2. My supervisor / co-workers listen to my personal problems.

3. My supervisor / co-workers are empathetic towards me.

4. My supervisor / co-workers show me esteem.

5. I feel personally and professionally recognized by my supervisor/co-workers.

6. My supervisor / co-workers protect me in case of "hard knocks".

7. My supervisor / co-workers encourage me in difficult times.

8. My supervisor / co-workers reassure me about my professional skills.

9. My supervisor / co-workers and I have a relation of mutual trust.

10. My supervisor / co-workers and I have a relation of mutual respect.

11. My supervisor / co-workers help me to put into perspective when things don't go.

12. My supervisor / co-workers help me to feel integrated in my work team.

13. My supervisor / co-workers help me to arrange my schedule in case of trouble.

14. My supervisor / co-workers and I communication easily on my personal problems.

15. My supervisor / co-workers and I communication easily on my professional problems.

16. My supervisor / co-workers advise and inform me whatever the problem I have to face.

17. My supervisor / co-workers help me to make my job easier. 


\section{APPENDix B - ScAles RESUlT}

\begin{tabular}{|c|c|c|c|}
\hline Componant and items & Community & Weight & Variance $(\%)$ \\
\hline $\begin{array}{l}\begin{array}{l}\text { Componant } 1 \\
\text { support }\end{array} \\
\text { s. Supervisor professional }\end{array}$ & & & 54.8 \\
\hline 4. My supervisor show me esteem & 0.78 & 0.86 & \\
\hline $\begin{array}{l}\text { 5. I feel personally and professionally } \\
\text { recognized by my supervisor }\end{array}$ & 0.77 & 0.84 & \\
\hline $\begin{array}{l}\text { 10. My supervisor and I have a relation of } \\
\text { mutual respect }\end{array}$ & 0.73 & 0.84 & \\
\hline $\begin{array}{l}\text { 9. My supervisor and I have a relation of } \\
\text { mutual trust }\end{array}$ & 0.7 & 0.8 & \\
\hline $\begin{array}{l}\text { 8. My supervisor reassure me about my } \\
\text { professional skills }\end{array}$ & 0.64 & 0.73 & \\
\hline $\begin{array}{l}\text { 13. My supervisor help me to arrange my } \\
\text { schedule in case of trouble }\end{array}$ & 0.47 & 0.62 & \\
\hline Componant 2 : Supervisor personal support & & & 11.6 \\
\hline $\begin{array}{l}\text { 2. My supervisor listen to my personal } \\
\text { problems }\end{array}$ & 0.8 & 0.88 & \\
\hline $\begin{array}{l}\text { 14. My supervisor and I communication easily } \\
\text { on my personal problems }\end{array}$ & 0.73 & 0.82 & \\
\hline 3. My supervisor are empathetic towards me & 0.6 & 0.67 & \\
\hline Total & & & 68.44 \\
\hline
\end{tabular}

Componant and items

Community $\quad$ Weight $\quad$ Variance (\%)

Collegial support
7 . My colleagues encourage $\mathrm{me}$ in difficult

time

11. My colleagues help me to put into

perspective when things don't go.

14. My colleagues and I communication easily

on my personal problems.

6. My colleagues protect me in case of "hord

8. My colleagues reassure me about my

professional skills

5. I feel personally and professionally

recognized by my colleagues

13. My colleagues help me to arrange my

schedule in case of trouble.

problems

68.44 
